\title{
Household Solid Waste Generation and Socioeconomic Factors in the Capital City of CAMBODIA
}

\author{
Yim Mongtoeun ${ }^{1 *}$, Takeshi Fujiwara ${ }^{2}$ and Spoann Vin ${ }^{3}$ \\ ${ }^{1}$ Department of Environmental Science, Royal University of Phnom Penh, Cambodia \\ ${ }^{2}$ Waste Management Research Center, Okayama University, Japan \\ ${ }^{3}$ Graduate School of Environmental and Life Science, Okayama University, Japan
}

Submission: May 22, 2019; Published: June 13, 2019

*Corresponding author: Yim Mongtoeun, Department of Environmental Science, Royal University of Phnom Penh, Room 112A, Building A, Russian Federation Blvd, Touk Laark I, Khan Toul Kork, Phnom Penh, Cambodia

\begin{abstract}
This paper presents the findings of study conducted in Phnom Penh city to find out the correlation between the generation of household solid waste and socioeconomic factors. The increasing of waste amount is a major issue and a challenge in urban area. The rising of waste amount associated with part of the social changes. These changes influence the size, structure and characteristic of households. The results show that $91 \%$ of people receive waste collection service. The rest (9\%), disposes their waste by burning (48\%), followed by throwing to open space $(29 \%)$ and throwing into water body $(15 \%)$. The perception toward to overall for waste collection company is $56 \%, 27 \%$, and $14 \%$ for neutral, unsatisfied and satisfied, respectively. While respondents (74\%) are acceptable with collection fee of USD1-USD2 (77\%). As for sorting, $95 \%$ of respondents sort waste before discharging. Waste discharge amount varies by household types: $1.8 \mathrm{~kg} / \mathrm{hh} / \mathrm{day}, 1.9 \mathrm{~kg} / \mathrm{hh} / \mathrm{day}, 2.7 \mathrm{~kg} / \mathrm{hh} /$ day by flat house, single house and villa, respectively. $92 \%$ of respondents express their interest in environmental issue with solid waste (64\%), followed by air pollution (39\%), and water pollution (22\%). People (91\%) have never heard the word 3Rs, while they do every day. $17 \%$ of waste will be reduced if people sort waste before discharging, furthermore it can make extra income with USD114/cap/year ( $\approx$ USD160million/year for whole city). The results also show that household solid waste generation and discharge is positively correlated to waste sorting activities, monthly income, family member, household types, and house size. It is also found that people are not aware of solid waste management, but they are willing to participate in environmental program (82\%) including solid waste management which account for $47 \%$ and $37 \%$ for recycling and waste separation, respectively.
\end{abstract}

Keywords: Household solid waste; Waste generation; Socioeconomics; Household size; Phnom penh

\section{Introduction}

Cambodia is one of the developing countries in Asian, especially in latest two decades the development of the country has been remarkable. Solid waste generation in Phnom Penh has drastically increased year by year due to urbanization, lifestyle changes and rapid population growth. Narayana (2008) also mentioned the increasing in per capita waste generation due to economic development, living standards improvement, and increasing the demands for goods and services. The information of municipal solid waste (MSW) is not available before 1994 because of lacking responsible ministry. The information of MSW was presented after MoE established in 1993, but not reliable. It seems MSW generation value $(0.05 \mathrm{~kg} / \mathrm{cap} /$ day $)$ reported from 1994-2002 was lower than actual. The annual waste generation dynamics in Phnom Penh indicated that increased from 0.136 million tons in 1995 to 0.361 million tons in 2008, and it will be 0.635 million tons in 2015 [1].
The objective of the paper is to figure out actual household waste generation and discharge based on waste survey, and the relationship between waste generation and relevant socioeconomic factors of households.

\section{Materials and Methods}

This study was conducted in Phnom Penh, capital city of kingdom of Cambodia, composing of 9 khans (districts) divided into 96 Sangkats (communes) and total population is approximate 1.4 million with land area about $679 \mathrm{~km} 2$. Phnom Penh city was selected for the research area based on the following factors: economic growth, urbanization, rapid population growth and development and at the same time solid waste generation is increasing as well. Five hundred and fifty-six (556) households were randomly selected by focusing on income strata. During the interview, research assistants go to each household to make face 
to face interview through questionnaires. It was sought to obtain information ranging from household personality, socioeconomic background to total waste generated and discharged. Each questionnaire contains 55 questions, mostly closed-ended questions, which related to socioeconomic characteristics such as age, gender, marital status, education, income, family size, household area, income and waste generation and attitudes towards waste, waste management behavior including disposal and separation and willingness to participate in waste management. Households selected for interview are divided into three different socioeconomic income strata:

a) low socioeconomic income strata-LSIS (USD0UDS500), b) middle socioeconomic income strata-MSIS (USD500USD900), and

c) high socioeconomic income strata-HSIS (>USD900).

\section{Results and Discussion}

\section{Waste generation and waste discharge}

\section{Waste generation by house size}

In Figure 1 shows that waste generation is associated with house size, the bigger house the more waste generated. We see that the house with $35 \mathrm{~m} 2$ and $95 \mathrm{~m} 2$ generate waste $1.6 \mathrm{~kg} /$ day and $2.24 \mathrm{~kg} /$ day, respectively. It means that the bigger house, the more numbers of people to live in, which is more related to waste generation with family member.

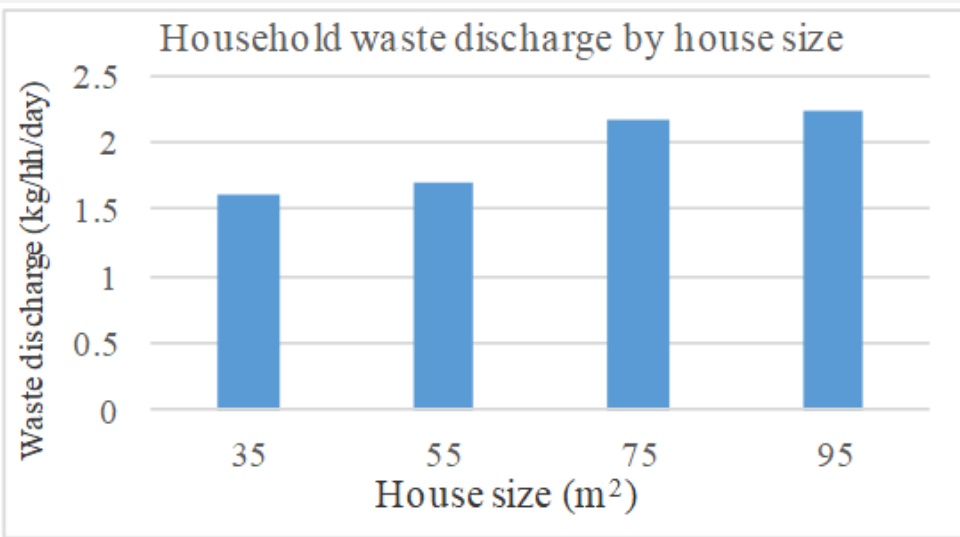

Figure 1: Waste generation based on house size.

\section{Relationship between waste generation and family member}

Figure 2 shows the waste generation per household per day and waste generation per person per day. The waste generation per household per day increases accordance with the increasing of number of family member, but in contrast waste generation per person per day is decrease with the family member increase because the more people can share more such as food, consumable materials and other things with less waste production. However, the waste generation in the city is proportional to number of people rise. The migration of people to capital is the main cause of increasing the number of people due to the more development, job and study opportunity and business. The immigration is a source of producing the huge quantities of solid waste in all main cities in Bangladesh [2].

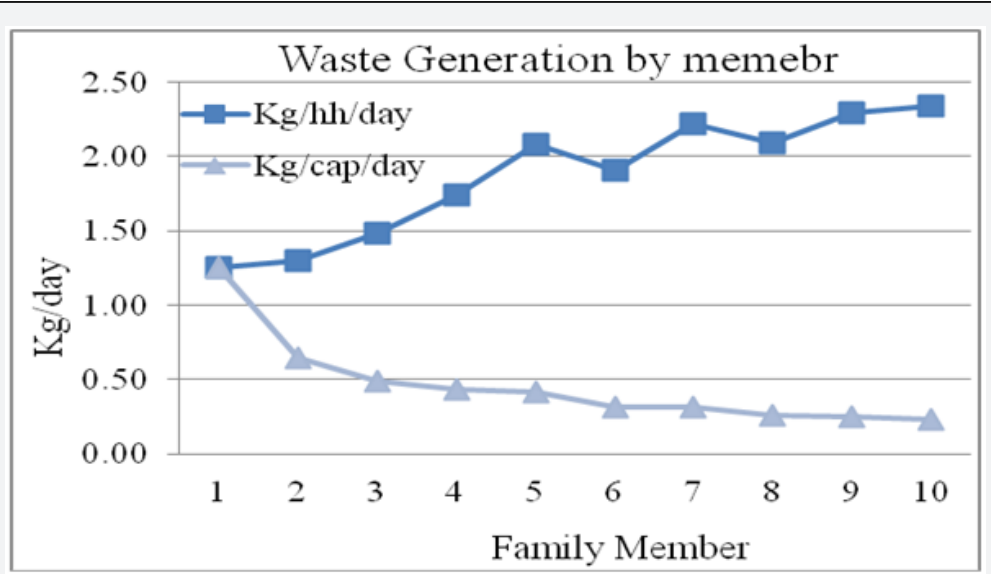

Figure 2: Waste generation with family member. 
Relationship between waste generation and household income

Figure 3 indicates that waste generation is associated to family income. The households with higher income produce more waste than low income households. This means that the rich families have more possibility and power to purchase things other than low income families. This trend was also found in the research conducted by Sujauddin et al. [3]. Shimelis [4] indicated that waste generation positively correlate with family size, income, and education levels. However, a study by Bruvoll [5] indicated that income did not influence the total generated municipal waste.

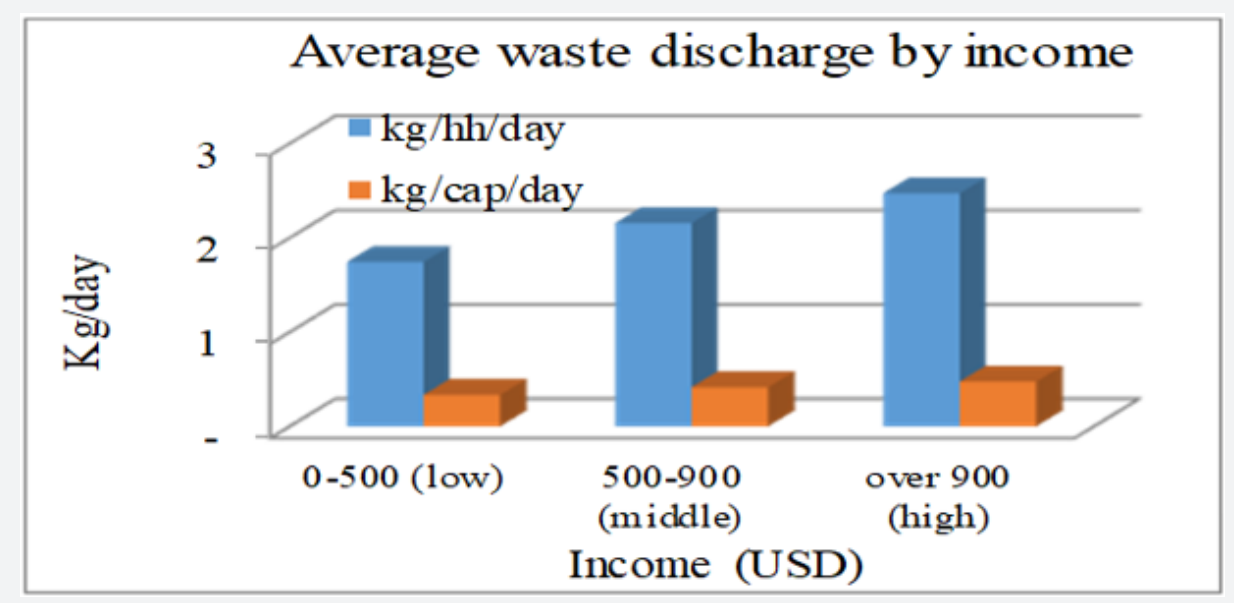

Figure 3: Waste generation with family income.

Relationship between waste generation and household type

In Table 1 indicates that the waste discharge is positively correlated with household type and household size, however, villa has smaller family member, but they produce more waste. It means the villa has high income, so income has much influence on waste generation.

Table 1: House type and waste generation.

\begin{tabular}{|c|c|c|c|c|c|}
\hline & Frequency & Percent (\%) & Household Size & $\mathbf{~ k g} / \mathbf{h h} / \mathbf{d a y}$ & $\mathbf{k g} / \mathbf{c a p} / \mathbf{d a y}$ \\
\hline Flat House & 277 & 49.82 & 5.25 & 1.81 & 0.34 \\
\hline Single House & 267 & 48.02 & 5.45 & 1.89 & 0.35 \\
\hline Villa & 10 & 1.8 & 4.9 & 2.7 & 0.55 \\
\hline Average & & & $\mathbf{5 . 2}$ & $\mathbf{2 . 1 3}$ & $\mathbf{0 . 4 1}$ \\
\hline
\end{tabular}

In Figure 4 shows the overall perception toward waste collection service which accounts for $56 \%$ and $26 \%$ of the respondents are neutral and $26 \%$, respectively even the collection

efficiency is improved. It means that the collection service is still poor in terms of time schedule, collection frequency, cleanliness and so on.

\section{Overal perception for waste collection service (\%)}

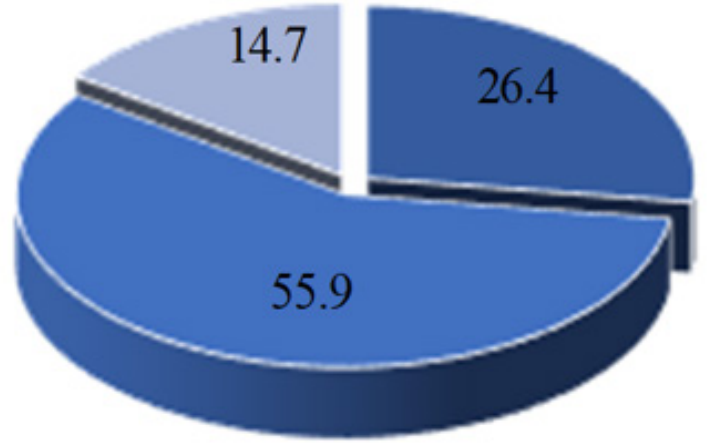

- Unsatisfied

- Neutral

" Satisfied

Figure 4: Perception toward waste collection service. 


\section{Conclusion}

The waste generation and waste discharge from households are closely dependent on socioeconomic parameters of each household. In this study we presented our findings of survey about relationship between waste generation and relevant socioeconomic parameters of households. The result shows that household solid waste discharge is positively correlated to waste sorting activities, monthly income, career, family member, type of household, and household size. Waste discharge amount varies by household types: $1.8 \mathrm{~kg} / \mathrm{hh} /$ day, $1.9 \mathrm{~kg} / \mathrm{hh} / \mathrm{day}, 2.7 \mathrm{~kg} /$ hh/day by flat house, single house and villa, respectively. People (91\%) have never heard the word 3Rs, while they do every day. $17 \%$ of waste will be reduced if people sort waste before discharging, furthermore it can make extra income with USD114/cap/year ( $\approx$ USD160million/year for whole city). We also found that people are not aware of solid waste management, but they are interested in environmental issue including solid waste management.

\section{References}

1. JICA (2005) The study on solid waste management in the municipality of Phnom Penh in the Kingdom of Cambodia. Kokusai Kogyo Co., Ltd.

2. Salequzzaman M, Awal M, Alam M (2001) Willing to pay community based solid waste management and its sustainability in Bangladesh. Proceedings of the International Conference "The Future is Here", RMIT, Melbourne, Victoria, January 15-29.

3. Sujauddin M, Huda SM, Hoque AT (2008) Household solid waste characteristics and management in Chittagong, Bangladesh. Waste Manag 28(9): 1688-1695.

4. Shimelis B (2011) Generation, Composition and Characteristics of urban Solid Waste in a Major Khat Producing and Marketing Area in Eastern Ethiopia. International Journal of Environmental Protection 1(5): 9-16.

5. Bruvoll A (2001) Factors influent a solid waste generation and management. Solid Waste Technology and Management 27: 156-162.

\section{Your next submission with Juniper Publishers will reach you the below assets}

- Quality Editorial service

- Swift Peer Review

- Reprints availability

- E-prints Service

- Manuscript Podcast for convenient understanding

- Global attainment for your research

- Manuscript accessibility in different formats ( Pdf, E-pub, Full Text, Audio)

- Unceasing customer service

Track the below URL for one-step submission https://juniperpublishers.com/online-submission.php 